\title{
The feeding of sledge dogs on Antarctic expeditions
}

\author{
BY N. W. M. ORR* \\ National Institute for Medical Research, Division of Human Physiology, \\ Medical Research Council, Hampstead, London, $\mathrm{NW}_{3}$ \\ (Received 20 fanuary 1965-Accepted 4 August 1965)
}

\begin{abstract}
I. The diets of sledge dogs at a British Antarctic sledging base were studied both at base and during sledge journeys, and samples of the diets and the relevant faeces were analysed. Changes in weight were related to calorie intakes. 2. The calorific requirements of sledge dogs were found to vary considerably from $\operatorname{dog}$ to dog and depended on the activity in which the dogs were involved. Whereas $2500 \mathrm{kcal} / \mathrm{dog}$ daily were just sufficient to maintain the bodyweight of a completely idle dog, $5000 \mathrm{kcal} / \mathrm{dog}$ were insufficient to maintain the body-weight of a dog pulling a heavy sledge over long distances. 3. Seal meat was found to be the most beneficial and most satisfactorily absorbed diet. The artificial diets, pemmican and Nutrican, were adequate to maintain body-weight if sufficient supplies were available to give dogs as much as twice the routine ration, but were uneconomical in that large quantities of nutrients were passed in the faeces.
\end{abstract}

Much can be expected of a sledge dog if it is adequately fed and properly trained. Dog transport has been used successfully by trappers and explorers in the Arctic for centuries. In the Antarctic where local game is not so readily available the problems of maintaining dogs on expeditions have been more serious and the production of an artificial sledging diet that is both nutritious and economical has been a matter of some importance.

The diet of sledge dogs in Antarctica has been studied by Taylor, Worden \& Waterhouse (1959) and Wyatt (1963). It was shown that pemmican, a concentrated diet consisting of beef meal and fat made by Bovril Limited, was inadequate to maintain body-weight during sledging journeys when used in the standard ration of $\mathrm{I} \mathrm{lb}$ $(0.45 \mathrm{~kg}) / \mathrm{dog}$ daily. The pemmican also provoked severe diarthoea and considerable amounts of nutrients were lost in the stools. A modified form of pemmican (Nutrican) was made by Bob Martin Limited and contained larger quantities of carbohydrate than the original pemmican. Nutrican caused less diarrhoea and diminished the loss of nutrients in the stools, but body-weights were not maintained on a ration of I lb/day. Taylor et al. (1959) showed that the energy expenditure of sledge dogs is high, and Wyatt (I963) estimated that a dog resting at base expended 2500$3000 \mathrm{kcal} / \mathrm{day}$, which during sledge journeys rose to $3800-4600 \mathrm{kcal} / \mathrm{day}$.

The experiments now described were designed to compare a modified form of Nutrican with the original Nutrican, with pemmican and with seal meat, and by comparing weight changes and performances of dogs on various quantities of the diet to make some estimate of their energy expenditure and nutritional requirements.

\footnotetext{
* Present address: Kent and Canterbury Hospital, Canterbury, Kent.
} 


\section{EXPERIMENTAL}

General

The experiments were carried out at Hope Bay, a British Antarctic Survey sledging base, situated at the northern tip of Grahamland (lat. $63^{\circ} 24^{\prime} \mathrm{S}$, long. $56^{\circ} 59^{\prime} \mathrm{W}$ ). Measurements were taken at base and during certain sledging journeys which the author made with surveyors, geologists or for physiological research.

Forty dogs were involved in trials which were conducted over 2 years. As far as possible the experiments were arranged so that they did not interfere with sledging and base routines and so that the dogs could be observed under conditions as nearly normal as possible. The ages of the dogs ranged from 9 months to 9 years : their bodyweights varied greatly with activity and feeding, but the average weight was $42.5 \mathrm{~kg}$ with a range of $37^{\circ} 0-47^{\circ} \mathrm{kg}$.

The dogs were given measured amounts of the four diets (seal meat, pemmican, original Nutrican and modified Nutrican) during the experiment. Samples of the diets were analysed at the Department of Experimental Medicine at Cambridge, and faeces collected during certain experiments were also analysed. Weight changes of the dogs were taken as an indication of the adequacy of the diets.

Dogs were weighed to the nearest $\mathrm{lb}(0.45 \mathrm{~kg})$ in the morning on a spring balance suspended from a tripod. The mean weight of each group at the beginning of each experiment was calculated, and subsequent weights have been presented as a percentage of the initial weight.

'The physical fitness of the dogs varied widely and depended on whether they were kept static at base, exercised in the normal course of base duties, or were travelling hard in the field. Distance travelled and changes in temperature, snow surfaces, loads, terrain and the morale of dogs and drivers all added to the variability, but in each experiment comparable dogs were exposed to the same conditions.

Uniform feeding presented no problems when the artificial diets were used: the feeds were supplied in $\mathrm{I} \mathrm{lb}\left(0^{*} 45 \mathrm{~kg}\right)$ blocks wrapped in paper. Uniform feeding with seal meat was more difficult and there were bound to be discrepancies between the amounts of blubber and lean meat in each feed.

\section{Chemical analysis of diets and faeces}

Analysis of the diets (Table I) showed that an arbitrarily chosen section of seal meat, including skin, blubber and meat, yielded nearly $2000 \mathrm{kcal} / \mathrm{lb}(0.45 \mathrm{~kg}) \mathrm{but}$ a pound $(0.45 \mathrm{~kg})$ of lean meat yielded only $500 \mathrm{kcal}$. Pemmican, the basis of which was beef and beef dripping, yielded about $2400 \mathrm{kcal} / 0.45 \mathrm{~kg}$ and was composed of $66 \%$ protein and $33 \%$ fat. Nutrican as supplied between 1956 and $195^{8}$ yielded $2500 \mathrm{kcal} /$ $0.45 \mathrm{~kg}$. The basis of this product was fish meal and it consisted of $30 \%$ protein, $40 \%$ fat and 10\% carbohydrate. The modified Nutrican as supplied after 1958 had whale meat as its basis and it yielded $2500 \mathrm{kcal} / 0.45 \mathrm{~kg}$ and was composed of $25 \%$ protein, $45 \%$ fat and $21 \%$ carbohydrate. Figures for halibut and stockfish, the favourite sledging diets of the Arctic, have been taken from McCance \& Widdowson (I960). 
Vol. 20

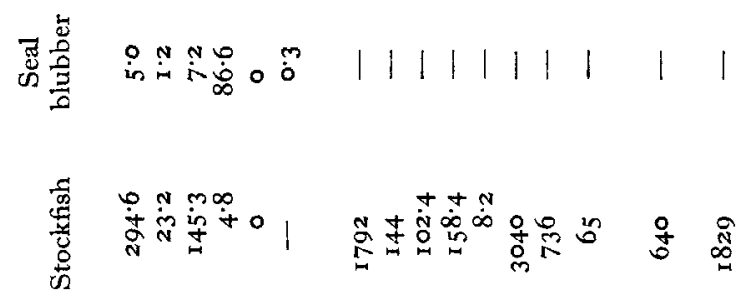

考

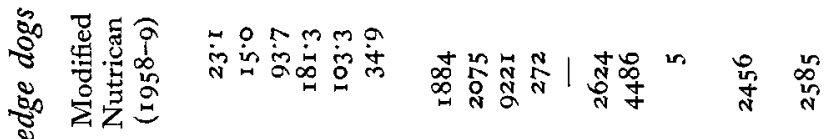

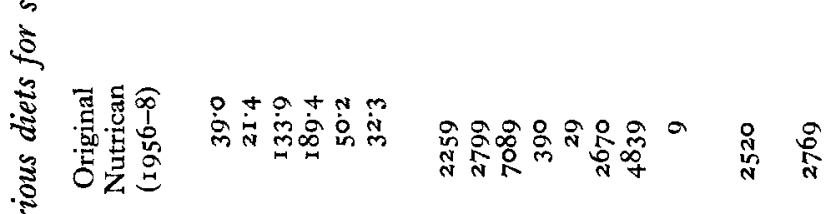

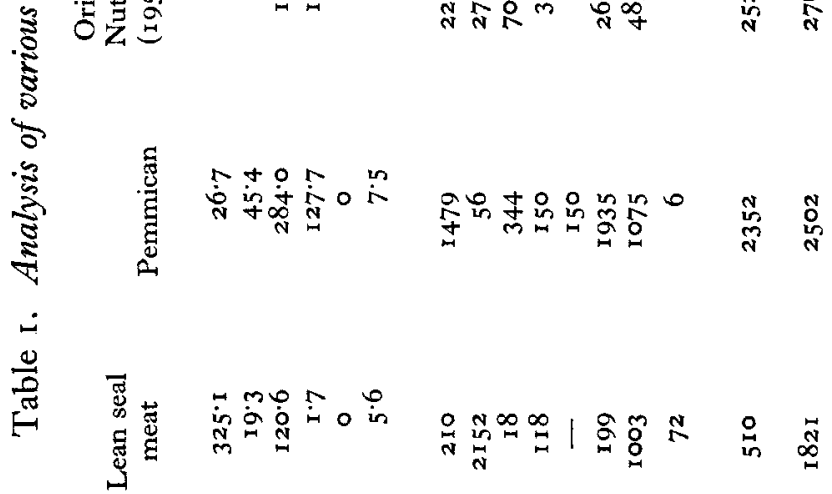

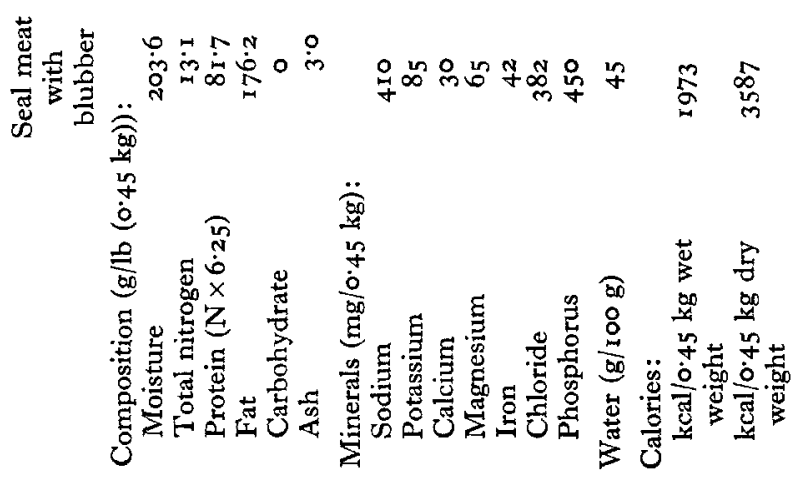


The most striking feature of a comparison of these foods is the very high calorific value of seal meat with blubber $(2000 \mathrm{kcal} / 0.45 \mathrm{~kg})$ and the low value for lean seal meat $(500 \mathrm{kcal} / \mathrm{o} \cdot 45 \mathrm{~kg})$. Only Nutrican contains any carbohydrate; the natural diets, and pemmican, are composed entirely of protein and fat.

Specimens of faeces were collected over $24 \mathrm{~h}$ whenever possible during the experiment and were kept frozen in polythene bags until they were returned to base. The total $24 \mathrm{~h}$ sample was weighed to the nearest gramme. The specimen was thawed, thoroughly mixed and a $30 \mathrm{~g}$ portion was dried over a water-bath for $\mathrm{IO} h$. The portion was reweighed and part of each sample was stored in an airtight glass tube for further analysis at Cambridge. There the faeces were dried to constant weight, and the total dry weight of each $24 \mathrm{~h}$ sample was calculated. Faecal nitrogen was measured by the micro-Kjeldahl method and faecal fat was determined by digestion with hydrochloric acid followed by extraction with diethyl ether (King, 1946). Changes in the weather or in sledging plans often resulted in specimens being spoiled or lost before they could be dried at base. In all, forty-two specimens were analysed from dogs fed on modified Nutrican, sixteen from dogs fed on pemmican and six each from dogs fed on fat seal meat and lean seal meat.

\section{Weight changes}

Expt $\mathrm{x}$. This was a base trial involving fourteen dogs and lasted $\mathrm{I} 7$ days. The dogs were divided into comparable groups of three and four dogs. They were not exercised during the course of the trial and were tethered at the end of $6 \mathrm{ft}$ chains on clean snow. The routine diet, which consisted of about $3.5 \mathrm{~kg}$ of seal meat on alternate days, was replaced by experimental diets: group I was given daily $0.45 \mathrm{~kg}$ of the original Nutrican/dog, groups 2 and $40^{\circ} 45 \mathrm{~kg}$ of the modified Nutrican and group 3 $0.45 \mathrm{~kg}$ of pemmican. The dogs were weighed at intervals.

Expt 2. This was a field trial in which one team was divided into two groups of four dogs. The dogs of one group were given daily $0.45 \mathrm{~kg}$ of modified Nutrican $/ \mathrm{dog}$ and the dogs of the other group were given $0.45 \mathrm{~kg}$ of pemmican. After 17 days the diets were reversed. The dogs were weighed at intervals. Twenty-four-hour samples of faeces were collected on four occasions.

The experiment lasted 29 days, during which time the team travelled 300 miles with heavy depot loads of up to $68 \mathrm{~kg} / \mathrm{dog}$ over sea-ice which was often broken and pressurized. The mean daily temperature was $-16^{\circ}$.

Expt 3. This experiment was a field trial in which one team was divided into two groups of three dogs. One group was given daily $0.45 \mathrm{~kg}$ of modified Nutrican $/ \mathrm{dog}$ and the other group $0.45 \mathrm{~kg}$ of original Nutrican. The dogs were weighed at intervals of 3-5 days. Twenty-four-hour samples of faeces were collected on 2 days.

The experiment was made on a survey journey. The dogs pulled medium loads over sea-ice and glaciers, covering 60 miles in 14 days. The mean daily temperature was $-19^{\circ}$.

Expt 4. In this experiment two teams travelled together. Both teams were given $2 \mathrm{lb}(0.9 \mathrm{~kg})$ of modified Nutrican/dog daily during the first 6 travelling days. During the next 13 days (days $\mathrm{I}-\mathrm{r} 3$ ) the dogs of team $\mathrm{I}$ were given $0.9 \mathrm{~kg}$ of Nutrican daily 
while the dogs of team 2 were given $0.45 \mathrm{~kg}$. During the next 9 days team 2 were given $0.9 \mathrm{~kg}$ and team I were given $0.45 \mathrm{~kg}$. Both teams returned to base on the $23^{\mathrm{rd}}$ day and were fed on seal meat. They were given seal daily for 3 days subsequently.

The dogs were weighed at daily intervals initially and on return to base. They were weighed every $3-4$ days in the period between.

The teams travelled together on the mainland, over glaciers and plateaus. They covered 200 miles in 28 days. The loads were only moderate but the snow was often soft and deep and the slopes steep. The mean temperature was around freezing point.

Expt 5. This was a field trial involving three teams. All the teams were given fresh seal meat on the first 3 travelling days. During the next $I 7$ days (days $I-I 7$ ) team $I$ were rationed to $0.45 \mathrm{~kg}$ modified Nutrican $/$ dog daily; the dogs of team 2 were given an extra $0.45 \mathrm{~kg}$ every 2nd day; and team 3 were given $0.9 \mathrm{~kg} / \mathrm{dog}$ daily. All teams were given unlimited seal on the 2 Ist day and subsequently. The dogs were weighed every 3 days until the 18 th day, after which they were weighed daily.

The teams travelled together and covered 440 miles of sea and shelf ice in 22 days. They carried heavy depot loads on the outward journey and returned with light sledges. The teams led in turn. The mean temperature during the experiment was $-8^{\circ}$.

\section{RESULTS}

\section{Total faecal excretion}

Dogs fed on lean seal meat or fat seal meat passed little dry matter ( 27 and $47 \mathrm{~g} /$ day) in their faeces (Table 2). When compared with the dry intake, these figures suggest an availability of $93-94 \%$ (Table 3). The dry weights of faeces of dogs fed on the

Table 2. Mean values for nitrogen and fat content of the faeces of sledge dogs given different diets

\begin{tabular}{|c|c|c|c|c|c|c|}
\hline Food & $\begin{array}{l}\text { No of } \\
\text { samples }\end{array}$ & $\begin{array}{c}\text { Dry } \\
\text { weight } \\
\text { of faeces } \\
(\mathrm{g} / 24 \mathrm{~h})\end{array}$ & $\begin{array}{c}\text { Nitroge } \\
\text { g/loog } \\
\text { (dry wt) }\end{array}$ & content & $\overbrace{\begin{array}{l}\mathrm{g} / 100 \mathrm{~g} \\
\text { (dry wt) }\end{array}}^{\text {Fat }}$ & $\mathrm{g} / 24 \mathrm{~h}$ \\
\hline Nutrican (I lb (o.45 kg) daily) & 42 & 67 & 5 & 4 & 37 & 25 \\
\hline Pemmican ( $0.45 \mathrm{~kg}$ daily) & I6 & го6 & I3 & 14 & 4 & 4 \\
\hline $\begin{array}{l}\text { Seal meat }(6 \mathrm{lb}(2.7 \mathrm{~kg}) \text { with } \\
\text { blubber alternate days) }\end{array}$ & 6 & 47 & 6 & 3 & 9 & 5 \\
\hline $\begin{array}{l}\text { Seal meat }(3 \mathrm{lb}(\mathrm{r} \cdot 35 \mathrm{~kg}) \text { lean } \\
\text { daily) }\end{array}$ & 6 & 27 & 6 & $\mathrm{r}$ & 12 & 3 \\
\hline
\end{tabular}

modified Nutrican were very uniform (mean $67 \mathrm{~g} /$ day) and indicate an availability of total dry matter of $85 \%$. The dogs that were fed on pemmican passed very much more (mean $106 \mathrm{~g} /$ day) and the figures indicate an availability of $76 \%$ dry weight. The figures of Taylor et al. (1959) for pemmican-fed dogs are similar (72\%). Wyatt's $\left(19^{6} 3\right.$ ) figures for total excretion are rather lower, but he attributes this to coprophagy.

\section{Nitrogen excretion}

Dogs fed on lean seal meat passed only $2 \%$ of the ingested nitrogen in their faeces, but dogs fed on pemmican and Nutrican passed $30 \%$ and $25 \%$ of the ingested 
nitrogen respectively. The high figure for nitrogen excretion for pemmican-fed dogs corresponds very closely to that of Taylor et al. (1959) (33\%). One can only conclude that processing in some way renders the protein of the artificial diets less digestible.

\section{Fat excretion}

The figures for fat excretion were more variable. The faeces of dogs fed on either lean seal meat or fat seal meat contained little fat $(12 \mathrm{~g} / \mathrm{ro0} \mathrm{g}$ faeces and $9 \mathrm{~g} / \mathrm{100} \mathrm{g}$ faeces), which suggests efficient absorption. Since measurements for the total fat intake with the natural diets were not uniform, a figure for fat availability has not been given in Table 3 .

\begin{tabular}{|c|c|c|c|}
\hline & Pemmican & Nutrican & Lean seal meat \\
\hline $\begin{array}{l}\text { Total dry intake } / 24 \mathrm{~h}(\mathrm{~g}) \\
\text { Total dry faeces } / 24 \mathrm{~h}(\mathrm{~g})\end{array}$ & $\begin{array}{l}427 \\
106\end{array}$ & $\begin{array}{r}43 \mathrm{I} \\
67\end{array}$ & $\begin{array}{r}387 \\
27\end{array}$ \\
\hline$\%$ available & 76 & 85 & 93 \\
\hline$\%$ excreted & 24 & 15 & 7 \\
\hline Total $\mathrm{N}$ intake $/ 24 \mathrm{~h}(\mathrm{~g})$ & 45 & 15 & 58 \\
\hline Total faecal N/24 h (g) & $\mathrm{r}_{4}$ & 4 & $\mathbf{I}$ \\
\hline$\%$ available & 70 & 75 & 98 \\
\hline$\%$ excreted & 30 & 25 & 2 \\
\hline Total fat intake $/ 24 \mathrm{~h}(\mathrm{~g})$ & 128 & I8I & 5 \\
\hline Total faecal fat $/ 24 \mathrm{~h}(\mathrm{~g})$ & 4 & 25 & 3 \\
\hline$\%$ available & 97 & 87 & - \\
\hline$\%$ excreted & 3 & 13 & - \\
\hline
\end{tabular}

Estimates for the availabilities of the components of fat seal meat have not been made because it was impossible to estimate the proportion of blubber to lean meat in each feed.

Pemmican-fed dogs produced faeces containing even less fat ( $4 \mathrm{~g} / \mathrm{roo} \mathrm{g})$. Only $3 \%$ of the ingested fat was excreted, indicating a high digestibility. This result is identical with the earlier findings of Taylor et al. (1959).

Dogs fed on Nutrican produced faeces containing $37 \mathrm{~g}$ fat in $100 \mathrm{~g}$ faeces. The availability of the ingested fat was only $87 \%$ as $13 \%$ was evacuated.

\section{Weight changes}

Expt $\mathrm{r}$. The mean weight of all the groups (except group 4) fell initially when the base diet of seal meat was changed to a sledging diet (Table 4). The weights remained

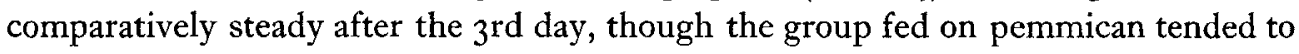
lose weight slowly but steadily.

The experiment showed that $2500 \mathrm{kcal} /$ dog daily were barely sufficient to maintain the body-weights of resting dogs and that an initial drop in weight may be expected when the bulky natural diet is replaced by a concentrated diet.

Expt 2. The dogs in both groups lost weight steadily (Table 5). The four dogs that were given $0.45 \mathrm{~kg}$ pemmican/day had lost $5 . \mathrm{I} \mathrm{kg}$ at the end of the 17 days. The four dogs that had been given $0.45 \mathrm{~kg}$ of modified Nutrican/day were $\mathrm{r} \cdot 8 \mathrm{~kg}$ lighter at the beginning of the experiment and lost $4.7 \mathrm{~kg}$ during the first 17 days.

When the diets were reversed there was a mean loss of $2.8 \mathrm{~kg}$ in both groups during 
'Table 4. Expt 1. Weight (kg) of sledge dogs on different diets

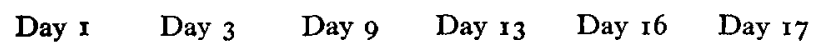

Group I: I lb $(0.45 \mathrm{~kg})$ original Nutrican daily

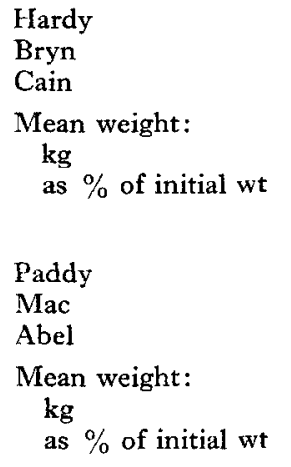

Fritz
Karl
Steak
Tarka
Mean weight:
$\quad$ kg \% of initial wt
$\quad$ as \% of

$\begin{array}{rlllll}38 \cdot 2 & 35 \cdot 9 & 34 \cdot 5 & 35 \cdot 5 & 35 \cdot 9 & 35 \cdot 5 \\ 42 \cdot 3 & 39 \cdot 1 & 38 \cdot 2 & 38 \cdot 6 & 38 \cdot 2 & 38 \cdot 6 \\ 37 \cdot 7 & 37 \cdot 3 & 37 \cdot 7 & 37 \cdot 3 & 36 \cdot 4 & 36 \cdot 4 \\ & & & & & \\ 39 \cdot 7 & 37 \cdot 4 & 36 \cdot 8 & 37 \cdot 1 & 36 \cdot 8 & 36 \cdot 8 \\ 100 & 94 & 93 & 93 & 93 & 93\end{array}$

Group 2: $0.45 \mathrm{~kg}$ modified Nutrican daily

$\begin{array}{clllll}39 \cdot 5 & 37 \cdot 7 & 37 \cdot 7 & 38 \cdot 2 & 38 \cdot 2 & 38 \cdot 6 \\ 39 \cdot 1 & 37 \cdot 3 & 37 \cdot 3 & 37 \cdot 3 & 37 \cdot 3 & 37 \cdot 7 \\ 37 \cdot 3 & 38 \cdot 2 & 38 \cdot 2 & 37 \cdot 3 & 37 \cdot 3 & 37 \cdot 3 \\ & & & & & \\ 38 \cdot 6 & 37 \cdot 7 & 37 \cdot 7 & 37 \cdot 6 & 37 \cdot 6 & 37 \cdot 9 \\ 100 & 98 & 98 & 97 & 97 & 98\end{array}$

Group 3: $0.45 \mathrm{~kg}$ pemmican daily

$\begin{array}{llllll}41 \cdot 4 & 39 \cdot 1 & 38 \cdot 6 & 37 \cdot 7 & 37 \cdot 3 & 37 \cdot 3 \\ 36 \cdot 8 & 36 \cdot 4 & 36 \cdot 4 & 35 \cdot 9 & 35 \cdot 5 & 35 \cdot 9 \\ 38 \cdot 2 & 36 \cdot 8 & 37 \cdot 3 & 36 \cdot 4 & 35 \cdot 9 & 36 \cdot 4 \\ 39 \cdot 5 & 38 \cdot 6 & 37 \cdot 3 & 37 \cdot 7 & 37 \cdot 7 & 36 \cdot 8 \\ & & & & & \\ 39 \cdot 0 & 37 \cdot 7 & 37 \cdot 4 & 36 \cdot 9 & 36 \cdot 6 & 36 \cdot 6 \\ 100 & 97 & 96 & 95 & 94 & 94\end{array}$

Group 4: $0.45 \mathrm{~kg}$ modified Nutrican daily

$\begin{array}{lllllll}\text { Eric } & 35 \cdot 9 & 35 \cdot 9 & 35 \cdot 5 & 33 \cdot 6 & 35 \cdot 5 & 35 \cdot 0 \\ \text { Ernst } & 39 \cdot 5 & 38 \cdot 6 & 37 \cdot 7 & 37 \cdot 3 & 37 \cdot 3 & 36 \cdot 4 \\ \text { Kid } & 39 \cdot 1 & 38 \cdot 6 & 37 \cdot 3 & 38 \cdot 6 & 37 \cdot 3 & 38 \cdot 6 \\ \text { Saki } & 40 \cdot 5 & 40 \cdot 5 & 38 \cdot 2 & 38 \cdot 2 & 38 \cdot 2 & 38 \cdot 2 \\ \text { Mean weight: } & & & & & & \\ \quad \text { kg } & 38 \cdot 8 & 38 \cdot 4 & 37 \cdot 2 & 36 \cdot 9 & 37 \cdot 1 & 37 \cdot 1 \\ \quad \text { as \% of initial wt } & 100 & 99 & 96 & 95 & 96 & 96\end{array}$

Table 5. Expt 2. Weight (kg) of sledge dogs on Nutrican and pemmican

Day I Day 7 Day I Day 15 Day 77 Day 20 Day 23 Day 29 Group $1: x \mathrm{lb}(0.45 \mathrm{~kg})$ pemmican daily

\begin{tabular}{|c|c|c|c|c|c|c|c|c|}
\hline \multirow[b]{2}{*}{ Karl } & & & & & \\
\hline & 40.9 & $37 \cdot 3$ & $35 \cdot 9$ & $37 \cdot 3$ & $36 \cdot 8$ & $36 \cdot 4$ & 34.5 & 34.1 \\
\hline Fritz & 40.0 & $37 \cdot 7$ & $36 \cdot 4$ & $35 \cdot 5$ & $36 \cdot 4$ & $36 \cdot 4$ & 35.5 & $33 \cdot 6$ \\
\hline Steak & 44.5 & $41 \cdot 4$ & $40 \cdot 0$ & $37 \cdot 7$ & $37 \cdot 3$ & $36 \cdot 8$ & $36 \cdot 4$ & $34 \cdot 5$ \\
\hline Tarka & 40.9 & $37 \cdot 3$ & $37 \cdot 3$ & $35^{\circ} 5$ & $35^{\circ} 5$ & $36 \cdot 4$ & 35.5 & $32 \cdot 7$ \\
\hline \multirow{4}{*}{$\begin{array}{l}\text { Mean weight: } \\
\mathrm{kg} \\
\text { as } \% \text { of } \\
\text { initial wt }\end{array}$} & & & & & & & & \\
\hline & $41 \cdot 6$ & $38 \cdot 4$ & $37 \cdot 4$ & $36 \cdot 5$ & $36 \cdot 5$ & $36 \cdot 5$ & $35 \cdot 5$ & $33 \cdot 7$ \\
\hline & 100 & 92 & 90 & 88 & 88 & & & \\
\hline & \multicolumn{4}{|c|}{ Group 2: $0.45 \mathrm{~kg}$ Nutrican daily } & \multicolumn{4}{|c|}{$0.45 \mathrm{~kg}$ pemmican daily } \\
\hline Eric & $38 \cdot 2$ & $36 \cdot 8$ & $33 \cdot 6$ & $35 \cdot 5$ & 35.0 & $34^{\circ} 5$ & $33 \cdot 6$ & $3 I \cdot 8$ \\
\hline Ernst & $40 \cdot 0$ & $3^{8 \cdot 2}$ & $36 \cdot 8$ & $35 \cdot 9$ & $35 \cdot 5$ & 35.9 & $34 \cdot 5$ & $32 \cdot 7$ \\
\hline Kid & $40 \cdot 0$ & $37 \cdot 3$ & $35 \cdot 9$ & 34.5 & $34 \cdot 5$ & $33 \cdot 6$ & $33 \cdot 6$ & 30.9 \\
\hline Saki & $42 \cdot 3$ & 40.5 & $38 \cdot 2$ & $37 \cdot 7$ & $3^{6 \cdot 8}$ & $3^{6 \cdot 4}$ & $3^{6 \cdot 4}$ & $34 \cdot 5$ \\
\hline \multicolumn{9}{|l|}{ Mean weight: } \\
\hline $\mathrm{kg}$ & 40.1 & $3^{8 \cdot 2}$ & $36 \cdot I$ & $35 \cdot 9$ & $35 \cdot 4$ & $35 \cdot 1$ & $34^{\prime} 5$ & $32 \cdot 5$ \\
\hline $\begin{array}{l}\text { as } \% \text { of } \\
\text { initial wt }\end{array}$ & 100 & 95 & 90 & 89 & 88 & 88 & 86 & $8 \mathrm{I}$ \\
\hline
\end{tabular}


the next 12 days. There was no significant difference between the weight changes of the Nutrican-fed dogs and the pemmican-fed dogs.

The experiment showed that dogs travelling Io miles/day with heavy depot loads lost weight steadily when fed on the routine rations yielding between 2400 and 2500 $\mathrm{kcal} / \mathrm{dog}$. They also became less responsive and more difficult to drive.

Expt 3. After 14 days of routine sledging rations the dogs that had been given $0.45 \mathrm{~kg}$ of modified Nutrican/dog daily had lost an average of $6.0 \mathrm{~kg}$. The dogs that had been fed on the original Nutrican had lost an average of $5.6 \mathrm{~kg}$. There was no significant difference between the weight loss in the two groups (Table 6).

\section{Table 6. Expt 3. Weight ( $\mathrm{kg})$ of sledge dogs on two forms of Nutrican}

\begin{tabular}{|c|c|c|c|c|c|}
\hline & Day $\mathbf{r}$ & Day 4 & Day 9 & Day II & Day I4 \\
\hline \multicolumn{6}{|c|}{ Group I: $\mathrm{l} \mathrm{lb}(0.45 \mathrm{~kg})$ modified Nutrican daily } \\
\hline Hardy & $39 \cdot 5$ & $38 \cdot 6$ & $36 \cdot 8$ & $36 \cdot 4$ & $35^{\circ} 9$ \\
\hline Bryn & $43 \cdot 6$ & $39 \cdot 5$ & 38.6 & $37 \cdot 3$ & $35 \cdot 9$ \\
\hline Cain & 45.0 & $43 \cdot 6$ & $41 \cdot 4$ & $40 \cdot 0$ & $38 \cdot 2$ \\
\hline \multicolumn{6}{|l|}{ Mean weight: } \\
\hline $\mathrm{kg}$ & $42 \cdot 7$ & 40.6 & $38 \cdot 9$ & $37 \cdot 9$ & $36 \cdot 7$ \\
\hline as $\%$ of initial wt & 100 & 95 & $9^{1}$ & 89 & 86 \\
\hline \multicolumn{6}{|c|}{ Group 2: $0.45 \mathrm{~kg}$ original Nutrican daily } \\
\hline Paddy & $40 \cdot 5$ & $39^{\circ} \mathrm{I}$ & $37 \cdot 3$ & $36 \cdot 4$ & $36 \cdot 4$ \\
\hline Mac & $43 \cdot 2$ & 40.9 & 39.5 & 37.7 & $37 \cdot 3$ \\
\hline Abel & $43 \cdot 6$ & $42 \cdot 3$ & $39 \cdot 5$ & $3^{8 \cdot 6}$ & $36 \cdot 8$ \\
\hline \multicolumn{6}{|l|}{ Mean weight: } \\
\hline $\mathrm{kg}$ & $42 \cdot 4$ & $40 \cdot 8$ & $38 \cdot 8$ & $37 \cdot 6$ & $36 \cdot 8$ \\
\hline as $\%$ of initial wt & 100 & 96 & 92 & 89 & 87 \\
\hline
\end{tabular}

Expt 4. Team $\mathrm{I}$ on $5000 \mathrm{kcal} / \mathrm{dog}$ daily gained weight steadily and on $2500 \mathrm{kcal} /$ dog daily lost weight steadily until, on the $23 \mathrm{rd}$ day, they were $0.2 \mathrm{~kg}$ below their initial weight (Table 7). Team 2 on the reverse diet lost weight and then gained weight until, on the 23 rd day, their mean weight was $0.9 \mathrm{~kg}$ over their initial weight.

When both teams returned to base well-fed and with their body-weights nearly back to their initial values, they showed remarkably little change when given large quantities of seal meat and soon lost interest in their unlimited food.

The experiment showed that it is not necessary for dogs to return from a sledge journey thin and voracious, and suggested that $\mathrm{I}_{2}^{\frac{1}{2}} \mathrm{lb}(0.68 \mathrm{~kg})$ of Nutrican/dog daily would probably be adequate to maintain the body-weights of dogs involved in moderate sledging activity.

Expt 5. All three teams lost weight initially (Table 8). The weights of team 3 on $5000 \mathrm{kcal} / \mathrm{dog}$ daily levelled out after 8 days; the weights of team 2 on $375^{\circ} \mathrm{kcal} / \mathrm{dog}$ daily levelled out after the $\mathbf{4}_{4}$ th day, possibly because a blizzard prevented any form of travel for 3 days between the $15^{\text {th }}$ and 28 th day; team I lost weight steadily throughout, and the dogs were $8.2 \mathrm{~kg}$ below their initial weight after I 8 days. Usually very willing, they became progressively more fractious and even when following tracks were unable to keep up with the other two teams.

When seal meat was offered on the 18 th day, the weight gains were proportionate to 
Vol. 20

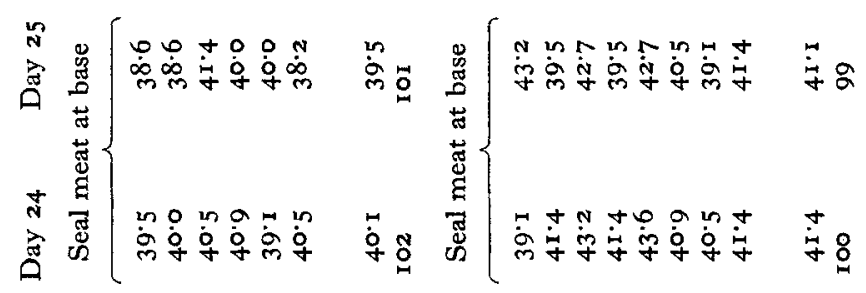

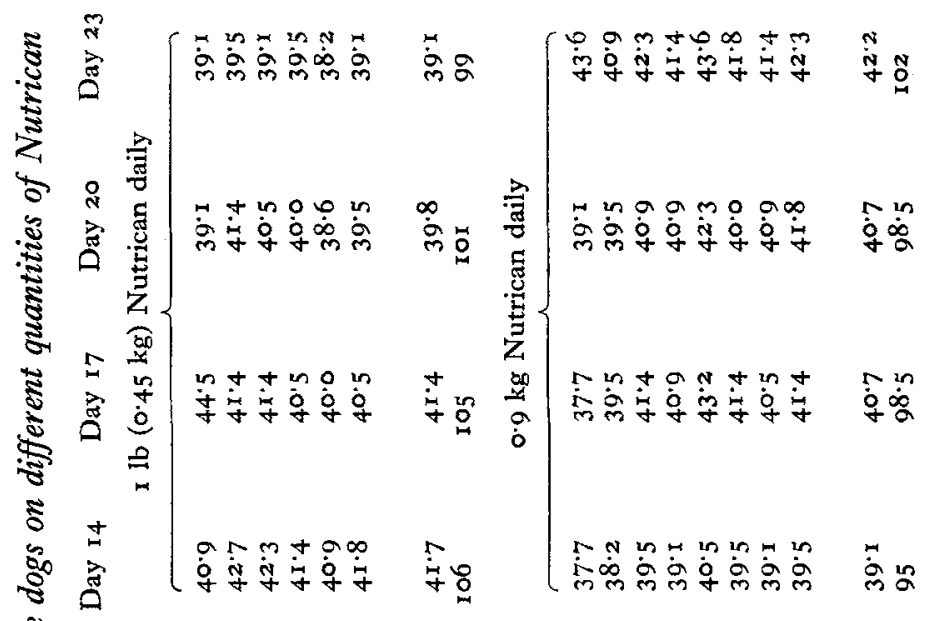

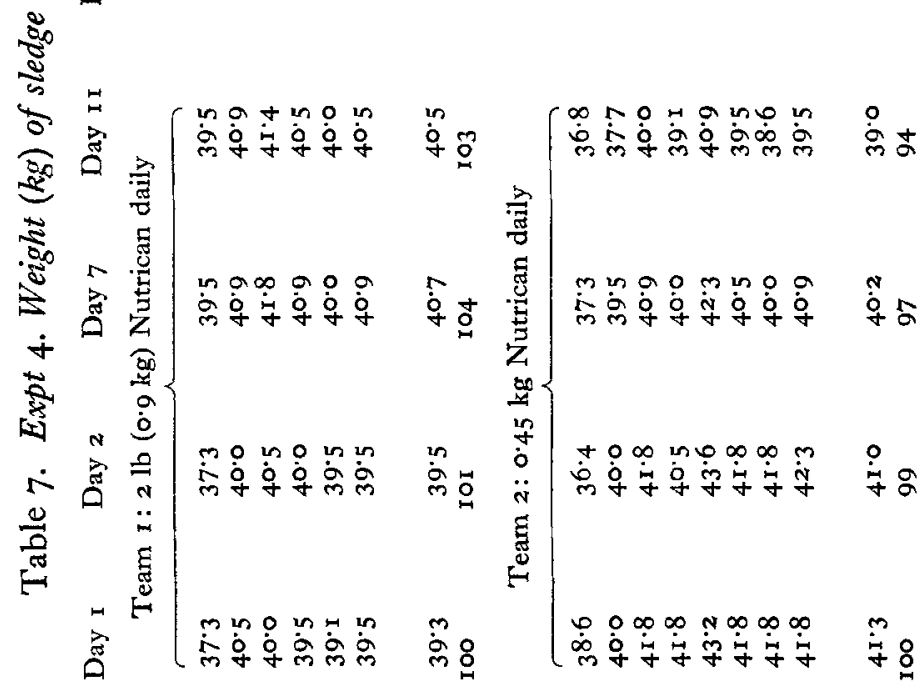

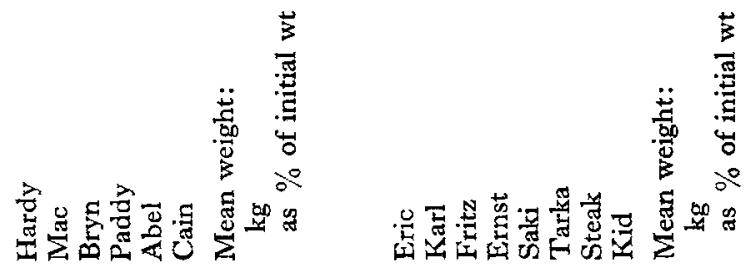



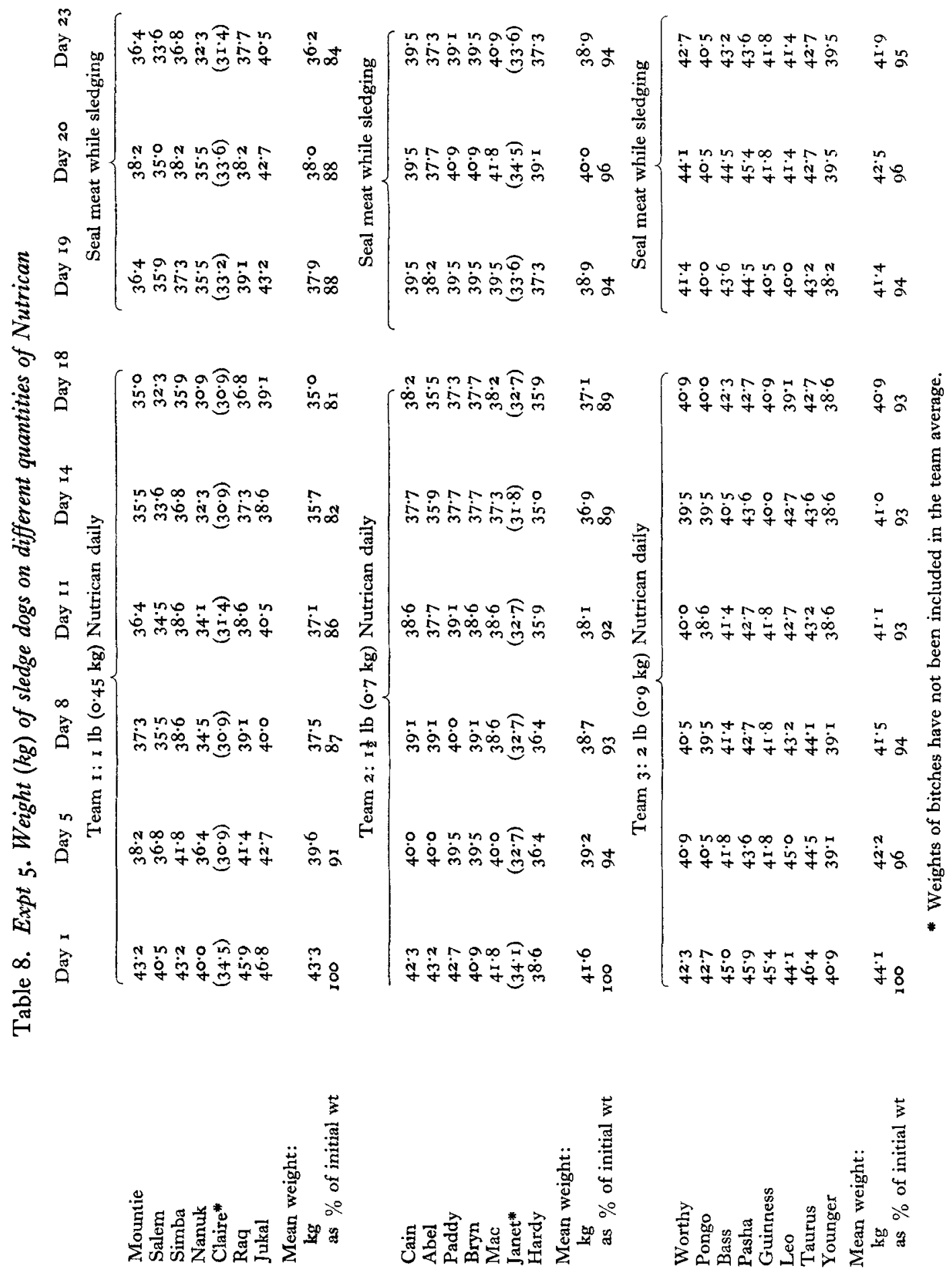
the overall weight losses. No team regained its initial weight, and after the first weight gain all the teams again lost weight during the subsequent 4 days.

The experiment showed that if dogs are travelling hard ( 20 miles/day) with heavy loads, $5000 \mathrm{kcal} / \mathrm{dog}$ daily are barely sufficient to maintain their body-weights.

\section{DISCUSSION}

In this series of experiments the adequacy of an artificial sledging ration for dogs has been compared with the natural diet of seal meat.

The findings of previous workers were confirmed when it was shown that the routine sledging ration ( $2500 \mathrm{kcal} / \mathrm{dog}$ daily), whether pemmican or Nutrican, was not sufficient to maintain the body-weights of husky dogs.

When fed on this ration while travelling, dogs lost weight in proportion to their initial body-weight and the work they had to do. Dogs travelling moderate distances with moderate loads ( $55 \mathrm{~kg} / \mathrm{dog}$ for ro miles/day) gained weight when they were given daily $5000 \mathrm{kcal} / \mathrm{dog}$, but this ration barely maintained the body-weights of the same dogs when they were travelling hard (20-30 miles/day).

From the figures in Table $x$ it is possible to compare the calorie values of some of the more successful diets that have been used in the Arctic and in the Antarctic. A basic ration advocated by Croft ( 1937$)$ of $6-8 \mathrm{lb}(2 \cdot 7-3 \cdot 6 \mathrm{~kg})$ of seal meat on alternate days would have provided the daily equivalent of $6000-8000 \mathrm{kcal} / \mathrm{dog}$. The $2-3 \mathrm{lb}(0.9-$ I.35 kg) daily of dried fish recommended by Hadwen (I937) and Rokeby-Thomas(1939) in the Arctic would have provided between 4000 and $6000 \mathrm{kcal} / \mathrm{dog}$. The addition of a 2 in cube of blubber, which Rokeby-Thomas (1939) suggested, would have given a total of between 5000 and $7000 \mathrm{kcal} / \mathrm{dog}$. As Wyatt (1963) has pointed out, it is unlikely that the ideal of providing a I lb $(0.45 \mathrm{~kg})$ block of concentrated food which is nutritionally adequate in all respects can be realized. Few except British Antarctic explorers have tried to realize it. The daily ration of pemmican yielding only $2400 \mathrm{kcal} /$ dog has never been satisfactory, but most researchers in the field have looked for faults in the quality of the diet rather than in its quantity.

The experiments described now emphasize that the energy expenditure of the working sledge dog is surprisingly high and confirm Wyatt's (I963) estimates in showing that a dog needs in the region of $5000 \mathrm{kcal} / \mathrm{day}$ if it is to maintain its bodyweight when travelling long distances.

The dogs lost weight initially when their diet was changed from seal meat to a concentrated ration, even if this ration was sufficient to maintain their body-weights subsequently. Although no doubt metabolic changes occurred with the change in diet, the sudden weight loss could most simply be explained by the sudden reduction in the bulk of food eaten. Similarly, when dogs that had been rationed on a concentrated sledging diet were given access to unlimited food the sudden dramatic weight gain was associated with the sudden increase in the amount of food eaten.

A comparison of the composition of sledging diets and faeces suggests that Nutrican is better utilized than pemmican. Certainly it does not cause the unpleasant diarrhoea that always afflicted dogs fed on pemmican. The main deficiencies of both artificial 
rations are that they do not supply sufficient calories to maintain the weight and efficiency of working dogs and, as the analyses showed, $15-25 \%$ of the artificial diets are wasted in the faeces.

A diet consisting entirely of protein and fat obviously suits a sledge dog perfectly well, and it may be that simply dehydrated lean seal meat supplemented with varying amounts of seal blubber will provide a more satisfactory sledging ration. No ration of as little as $0.45 \mathrm{~kg} / \mathrm{dog}$ daily can possibly provide adequate calories to maintain the weight and stamina of a working sledge dog.

\section{REFERENCES}

Croft, A. (1937). Polar Rec. 2, 68.

Hadwen, S. (1937). Polar Rec. 2, 59.

King, E. J. (I946). Microanalysis in Medical Biochemistry. London: J. and A. Churchill.

McCance, R. A. \& Widdowson, E. M. (1960). Spec. Rep. Ser. med. Res. Coun. no. 297.

Rokeby-Thomas, H. R. (1939). Geogrl F. 93, 424.

Taylor, R. J. F., Worden, A. N. \& Waterhouse, C. E. (1959), Br. F. Nutr. r3, x.

Wyatt, H. T. (1963). Br. F. Nutr. 17, 273. 